\title{
Increasing Cellulose Production from Rhizobium leguminosarum bv. viciae
}

\author{
Suaad Ali Ahmed, Alaa Raheem Kazim and Hussam Mahmood Hassan \\ Department of Biology, College of Science, University of Baghdad, Baghdad-Iraq.
}

\begin{abstract}
Bacterial cellulose (BC) is a type of biopolymer produced as primary metabolism product by many genera of bacteria such as Acetobacter, Rhizobium, Agrobacterium, Psuedomonas and Sarcina. This article aimed to study the effect of some factors on cellulose production from Rhizobium leguminosarum bv. viciae which isolated from root nodules of Vicia faba plant collected from Abu-Ghraib in Baghdad. Some environmental and nutritional factors were examined including : carbon and nitrogen sources, $\mathrm{pH}$, temperature and incubation period. Results showed that maximum production of cellulose was gained by Hestrin-Schram medium (HS medium) containing $2 \%$ fructose as carbon source, $1 \%$ yeast extract as nitrogen source, as well as optimum $\mathrm{pH}$, temperature, and incubation period were $\left(5,30^{\circ} \mathrm{C}\right.$ for 7 days) respectively .Cellulose dry weight was analyzed by Fourier transform infrared spectroscopy (FTIR) technique and the results showed the presence of the functional groups of bacterial cellulose. [DOI: 10.22401/JNUS.20.1.17]
\end{abstract}

Keywords: Bacterial cellulose (BC), Rhizobium leguminosarum, Hestrin-Schram medium (HS medium).

\section{Introduction}

Bacterial cellulose (BC) is a natural polysaccharide and produced as primary metabolite [1]. Bacteria belongs to the genera of Acetobacter, Rhizobium, Agrobacterium, Psuedomonas and Sarcina demonstrated the ability to synthesize $\mathrm{BC}$ as a linear chain of several hundred to many thousands of $\underline{\beta(1 \rightarrow 4)}$ linked D-glucose units [2].

$\mathrm{BC}$ is composed of pure cellulose without lignin, hemicellulose, and other substances . It has a high degree of polymerization, strong mechanical and preferential orientation specificities with absorbent properties [2]

$\mathrm{BC}$ is experiencing a major interest and being widely investigated as a new type of material due to its non -toxic and non- allergic materials with important physiochemical properties include: fine fiber net work, high water holding capacity, biocompatibility, high tensile strength, high crystallinity, high degree of polymerization, high purity, elasticity and durability $[3,4]$.

The physiochemical properties of BC differ from those of plant cellulose and it has important applications in industry, moreover, $\mathrm{BC}$ could be purified more easily than plant cellulose [4]. BC is used in many special applications such as food productions as: an additive, emulsifier, dietary fiber and edible preservative in addition to medical applications as barrier against bacterial growth
[3,5], as a scaffold for tissue engineering of cartilages, and blood vessels as well as for artificial skin for temporary covering of wounds [6,7].

The present work was carried out to study the effect of some environmental and nutritional factors for enhancement of cellulose production from Rhizobium leguminosarum bv. viciae.

\section{Materials and methods \\ Sample collection}

Root nodules of Vicia faba plant were collected from a farm located in Abu-Ghraib, in Baghdad in sterile container.

\section{Isolation and identification of Rhizobium leguminosarum bv. viciae}

The vitality root nodules were chosen and washed with tap water to remove soil particles, after that root nodules were sterilized with 95\% ethanol, then washed several times with sterile distilled water (D.W.) to remove the effect of ethanol. The nodules were crushed with sterilized needle and mixed with D.W. to form suspension of nodules which used to study the morphological and cultural characteristics for full identification of Rhizobium leguminosarum bv. viciae. The morphological identification was done by taking a loopfull from the suspension, and spread on a glass slide, then examined under 
microscope, while the cultural characteristics were done by culturing the suspension on Mannitol Yeast Extract Agar (MYA) and incubated at $25^{\circ} \mathrm{C}$ for 3-5 days [8,9].

\section{Detection and extraction of Rhizobium leguminosarum bv. viciae cellulose}

The ability of isolated Rhizobium leguminosarum bv. viciae to produce cellulose was examined by inoculating flasks containing $100 \mathrm{ml}$ of cellulose production medium (HSmedium) with $1 \mathrm{ml}$ of fresh culture of bacterial isolate and incubated at $30^{\circ} \mathrm{C}$ for one week. Cellulose production was investigated as the appearance of white pellicle of cellulose on the surface of culture medium.

Cellulose was extracted from the production medium according to Son et al. (2002) [10], by harvesting cellulose pellicles by filtration throughout filter paper whatman No.1, then washed with distilled water, heated in a water bath with $0.5 \% \mathrm{NaOH}$ at $80^{\circ} \mathrm{C}$ for $15 \mathrm{~min}$ to remove microbial cells and medium components, then washed with distilled water, placed in a petri dish, dried in an oven at $105^{\circ} \mathrm{C}$ for $1-2 \mathrm{hr}$. to determine cellulose dry weight.

Fourier transform infrared spectroscopy analysis for Rhizobium leguminosarum bv. viciae cellulose

The dry weight of bacterial cellulose was analyzed by FTIR by taking small amount of powder cellulose, mixed with potassium bromide $(\mathrm{KBr})$ crystals at ratio 1:10 (w/w), put in a cap and compressed to compose a thin pellet and the spectrum of the pellet was obtained by Shimadzu FTIR spectrophotometer [11].

\section{Determination of optimum conditions for cellulose production from Rhizobium leguminosarum bv. viciae \\ 1- Effect of carbon sources}

To study the effect of different carbon sources on the cellulose production, $100 \mathrm{ml}$ of sterilized Hestrin-Schram medium (HSmedium) with $2 \% \mathrm{w} / \mathrm{v}$ of different carbon sources (fructose, sucrose, glucose, mannitol, and dates molasses) were prepared and inoculated with $1 \%$ of activated bacterial culture broth (optical density, 0.1). The media were incubated for one week at $30^{\circ} \mathrm{C}$ bacterial cellulose, extracted, dried and weighted.

\section{2- Effect of nitrogen source}

One- handred $\mathrm{ml}$ of sterilized HS- medium with optimum carbon source (fructose) was prepared with different nitrogen sources at a concentration of $1 \%(\mathrm{w} / \mathrm{v})$ (peptone, malt extract, yeast extract, ammonium sulphate, and urea), inoculated with $1 \%$ of activated bacterial culture and incubated for one week at $30^{\circ} \mathrm{C}$. Cellulose was extracted and dry weight was measured.

\section{3- Effect of pH}

Cellulose production media were prepared at different $\mathrm{pH}$ values $(5,5.5,6,6.5,7$ and 7.5$)$ with fructose and yeast extract as carbon and nitrogen sources, inoculated with $1 \%$ of activated bacterial culture and incubated for one week at $30^{\circ} \mathrm{C}$. Cellulose was extracted and dry weight was recorded.

\section{4- Effect of incubation temperature}

Cellulose production medium with optimum carbon and nitrogen sources and optimum $\mathrm{pH}$ (5) was incubated at different temperatures $(20,25,30,37,40 \text { and } 45)^{\circ} \mathrm{C}$ for one week, after inoculation with $1 \%$ of activated bacterial culture then cellulose was extracted and dry weight was recorded.

\section{5- Effect of incubation periods}

Cellulose production medium with optimum carbon, nitrogen sources and optimum $\mathrm{pH}(5)$, was inoculated with $1 \%$ of activated bacterial culture (optical density, 0.1 ) and incubated at $30^{\circ} \mathrm{C}$ for $1,3,5,7$ and 9 days after each incubation period, cellulose was extracted and dry weight was recorded.

\section{Results and discussion}

\section{Isolation and identification of Rhizobium leguminosarum bv. viciae}

$R h$. leguminosarum bv. viciae was isolated from vitality root nodules, then identified depending on morphological, culture characteristics and microscopic examination [12,13]. Morphological and culture characteristics depending on the appearence of bacterial colonies on mannitol yeast extract agar (MYA).The colony seemed as large milky-white, shiny and raised with a circular shape colonies, highly mucoid. Under 
microscopic examination it appeared as gram negative and rod shaped bacteria.

Detection and extraction of Rhizobium leguminosarum bv. viciae cellulose

$R h$. leguminosarum bv. viciae isolate was examined for their ability to produce cellulose by culturing on HS broth medium. Cellulose dry weight produced was determined. Results showed that $\underline{R h}$. leguminosarum bv. viciae isolate can produce cellulose and cellulose dry weight produced from this isolate was $6.8 \mathrm{~g} / \mathrm{L}$ which can be seen as white pellicle formed on the surface of HS medium.

\section{Fourier transform infrared spectroscopy} (FTIR) analysis of Rhizobium leguminosarum bv. viciae cellulose

The analysis of the crude cellulose fractions was done by FTIR technique, the results exhibited the presence of $\mathrm{O}-\mathrm{H}$ stretching group in $3409.91 \mathrm{~cm}^{-1}$, bending groups of $\mathrm{C}-\mathrm{H}$ and $\mathrm{H}-\mathrm{C}-\mathrm{H}$ in $2929.67 \mathrm{~cm}^{-1}$ and $2869.88 \mathrm{~cm}^{-1}, \mathrm{C}-\mathrm{C}$ group presence at $1446.51 \mathrm{~cm}^{-1}$, The C-O-C groups stretching vibration appears at 1081 . $99 \mathrm{~cm}^{-1}$. Fig.(1)

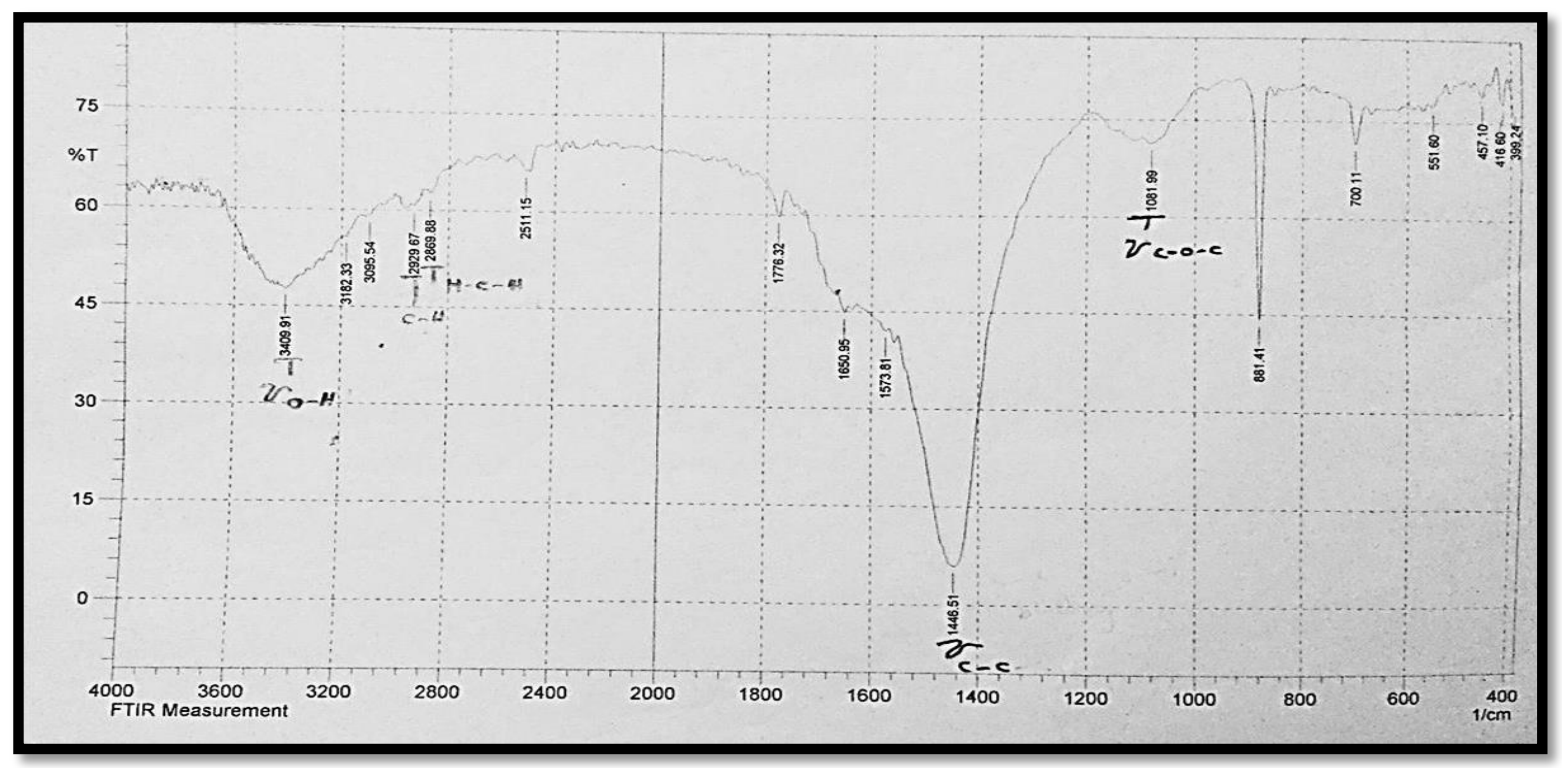

Fig.(1) FTIR analysis of cellulose produced from Rhizobium leguminosarum bv. viciae.

The optimum conditions for cellulose production from Rhizobium leguminosarum bv. viciae.

\section{1- Effect of carbon sources}

The results of dry weights of cellulose were fructose 8.4, mannitol 6.6, date molasses 6.2, sucrose 5.8 and glucose $4.9 \mathrm{~g} / \mathrm{L}$ Fig.(2). The best carbon source for production of bacterial cellulose was fructose at $2 \%$ [14]. The lowest production of cellulose in a medium containing glucose as carbon source was due to the formation of gluconic acid and ketogluconic acid as by product which leads to lower the $\mathrm{pH}$ of the medium and inhibited cell growth and decreased the production of bacterial cellulose $[15,16]$. Medium with date 
molasses as carbon source increased the production of cellulose more than the medium supported with glucose as carbon source [16].

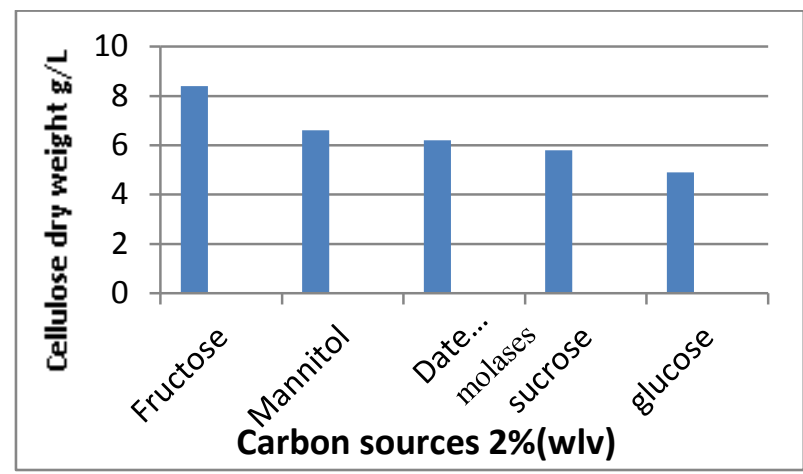

Fig.(2): Cellulose production from

Rhizobium leguminosarum bv. viciae in $\mathrm{HS}$ medium supplemented with $2 \%$ of different carbon sources

\section{2- Effect of nitrogen sources}

The maximum production of cellulose was gained by supplementing production medium (HS) with yeast extract and the dry weight was $(7.8 \mathrm{~g} / \mathrm{L})$ when compared with other nitrogen sources. The dry weights of cellulose gained by supplementing the production medium with different nitrogen sources were (yeast extract 7.8 , malt extract 6.9 , pepton 6.3 , urea 4.2 and ammonium sulphate 1.5) g/L. The essential component of proteins is nitrogen, which plays an important role in bacterial metabolism, increased bacterial growth and providing it with essential vitamins chiefly vitamin B complex, that afford the requirements for microorganism for growth and cellulose production $[17,18]$.

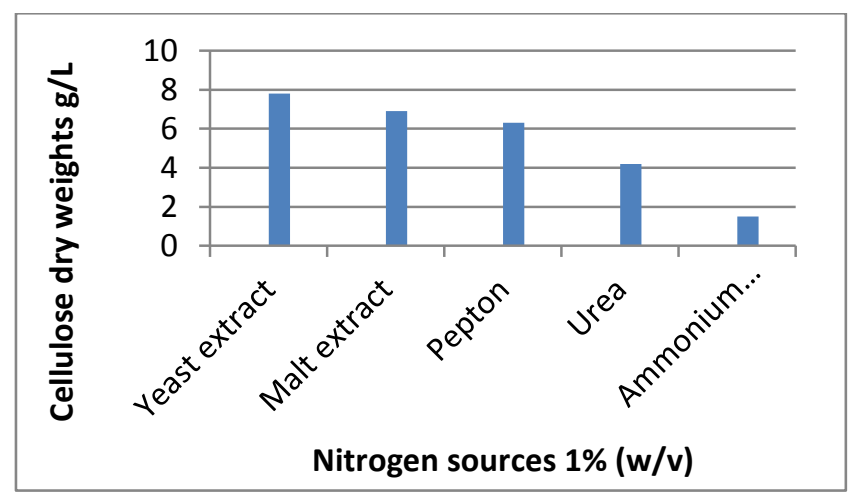

Fig.(3) Cellulose dry weights produced from Rh. leguminosarum bv. viciae in HS- medium supplememting with $1 \%$ of different nitrogen sources.

\section{3- Effect of $\mathrm{pH}$ on cellulose production}

The greatest production was gained at $\mathrm{pH}$ (5), and the dry weight was $(7.1 \mathrm{~g} / \mathrm{L})$ while in $\mathrm{pH}$ greater than 5 there were decrease in cellulose production. Cellulose dry weights obtained from treated production medium with different $\mathrm{pH}$ values $(5,5.5,6,6.5,7$ and 7.5$)$ were $(7.1,6.3,5.7,5.1,3.2$ and 2.4$) \mathrm{g} / \mathrm{L}$ respectively Fig.(4).

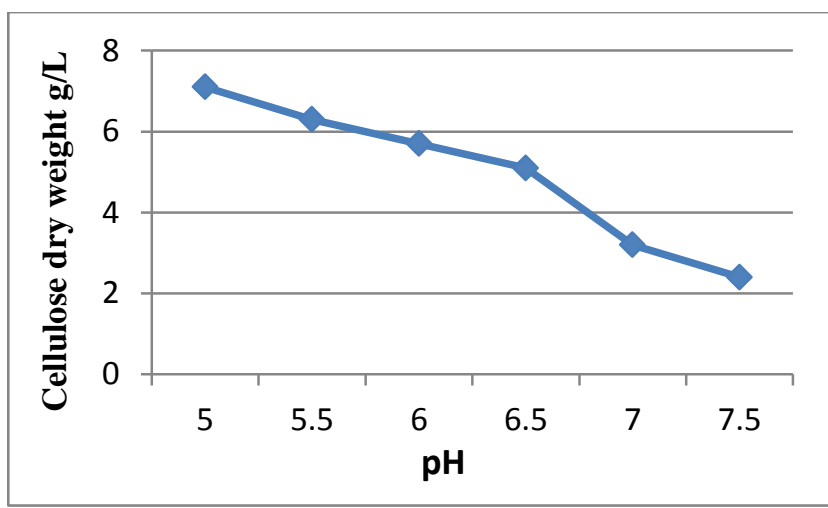

Fig.(4): Effect of $\mathrm{pH}$ on cellulose production from Rh. leguminosarum bv. viciae

The $\mathrm{pH}$ of production medium decreased during production processes due to formation and the accumulation of lactic acids, gluconic acid, acetic acid in the culture medium which impede bacterial growth and cellulose productivity [17].

\section{4- Effect of incubation temperature on cellulose production}

Results showed that maximum cellulose production was at $30^{\circ} \mathrm{C}$. However, cellulose production decreased at temperature above $30^{\circ} \mathrm{C}$ and less than $25^{\circ} \mathrm{C}$. The dry weights of cellulose gained from incubation the production medium at different temperatures $(20,25,30,35,40$ and 45$)$ were $(3.8,7.2,7.5$, 4.3, 3.2 and 1.3) g/L respectively Fig.(5).

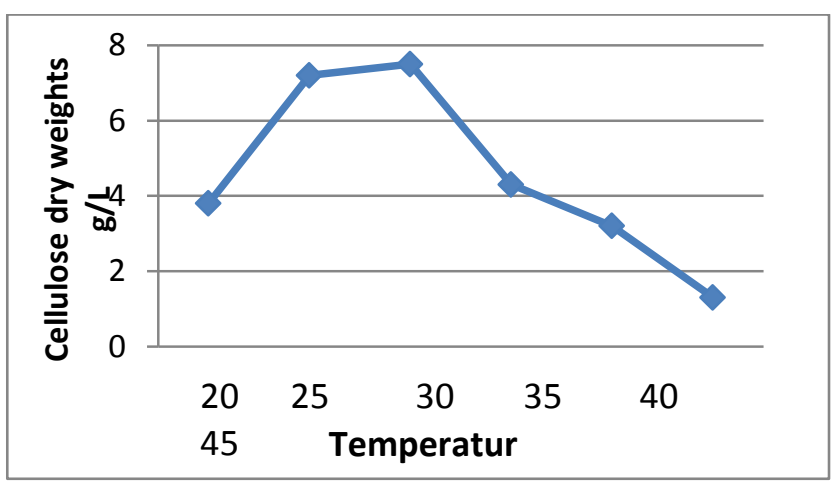

Fig.(5): Effect of different incubation temperatures on cellulose production from Rh. leguminosarum bv. Viciae. 
There are many types of enzymes responsible for conversion of carbohydrates to cellulose and the best temperature for these enzymes was at between $(28-30)^{\circ} \mathrm{C}$. At temperatures above $31^{\circ} \mathrm{C}$, the production of cellulose was lowered due to inactivation of metabolic enzymes at these temperatures [19].

\section{5- Effect of incubation periods on cellulose production}

The results showed that the maximum amount of cellulose was obtained in incubation period of 7 days while the amount of cellulose declined in incubation periods below and over than 7 days. The dry weights of cellulose gained at different incubation periods $(1,3,5$, 7 and 9) days were $(0.4,2.5,5.7,7.2$ and 4.6) $\mathrm{g} / \mathrm{L}$ respectively Fig.(6). The changes in the bacterial cellulose concentration in the fermentation medium occurred after 7-18 days of fermentation, the amount of glucose was almost exhausted and the metabolites had reached maximum production at this time. Therefore, there was an increase in the bacterial cellulose at incubation periods reach to 7-18 days [17].

The dry weight and the yield of bacterial cellulose increased quickly after a few days of incubation, and the production reached to maximum after 2 weeks [18]. The bacterial cell mass deceased over time, and the production of cellulose happened through the exponential growth phase, and the maximum production in the stationary phase. There was no production of polysaccharides during the decline phase [19].

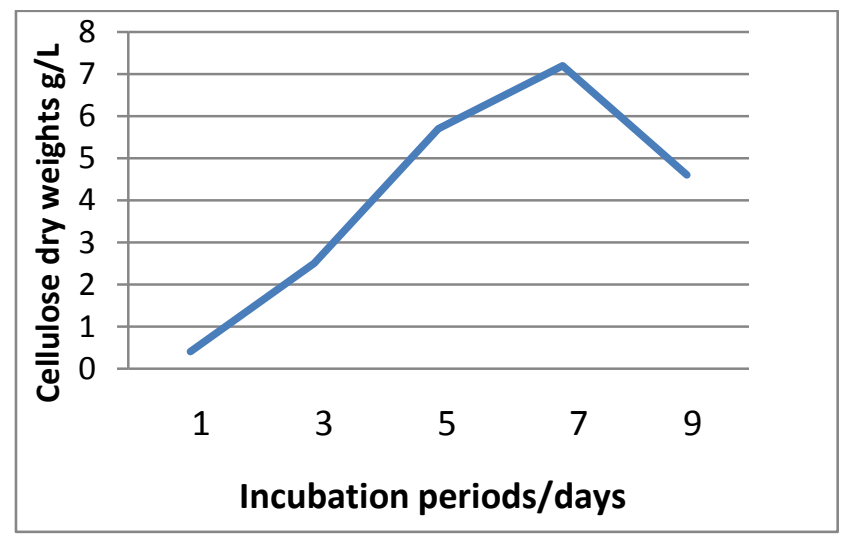

Fig.(6): Effect of different incubation periods on cellulose production from $R$. leguminosarum bv. viciae

\section{Conclusion}

Fourier transform infrared spectroscopy analysis for cellulose production from Rhizobium leguminosarum bv. viciae showed the presence of O-H, C-H , H-C-H,C-C, and $\mathrm{C}-\mathrm{O}-\mathrm{C}$ groups which acts as functional groups in cellulose structure. The optimal conditions for cellulose production from Rhizobium leguminosarum bv. Viciae were: $(2 \% \mathrm{w} / \mathrm{v})$ fructose as carbon source, $(1 \%)$ yeast extract as nitrogen source, $\mathrm{pH}$ (5), incubation temperature $\left(30^{\circ} \mathrm{C}\right)$, and incubation period was (7 days).

\section{Reference}

[1] Retegi A., Gabilond N., Pena C., Zuluga R., Castro C., Ganan P. and Delacaba K. "Bacterial cellulose films with controlled microstructure - mechanical property relationships.", Cellulose, 17, 661-669, 2010.

[2] Nagwa A., Ahmed I., Houssni E. and Altaf H. B., "Improvement in bacterial cellulose production using Glucon acetobacterxylinus ATCC 10245 and characterization of the cellulose pellicles produced", Egypt Pharm J., 14, 123-129, 2015.

[3] Denise M., Rosilene A., Adenise L. and Gilvan W., "Application of bacterial cellulose conservation of minimally processed fruits", Revista Brasileir de Tecnologia Agroindustrial, 5(1), 356 - 366, 2011.

[4] Marzieh M. and Ali Y., "Investigations of physiochemical properties of the bacterial cellulose produced by Gluconaceto bacterxylinum from date syrup", World Academy of Sciences Engineering and Technology, 6, 2010.

[5] Pacheco J., Yee S., Zentalla M. and Marvan E., "Cellulos abacteriana en Gluconacetobacterxy linum: Biosintesisy Aplicaciones", Revista Especializada en Ciencia Quimico - Biolōgica,. 7(1), 18-25, 2004.

[6] Klemm D., Schumann D., Udhardt U. and Marsch S., "Bacterial synthesized cellulose - artificial blood vessel for microsurgery", Progress in Polymer Science,. 26(9), 1561 1603, 2001. 
[7] Elham E. and Amir K., "Influence of Fermentation Conditions and Alkali Treatment on the Porosity and Thickness of Bacterial Cellulose Membranes", J Science and Technol, 3( 2), 194-203, 2013.

[8] Altaee M. I. and Almolla Z. S., "Effect study of Rhizobium leguminosarum bv.Viciae on some fungi groups growth", Tikrit J. of pure sciences, 15(1), 2010.

[9] Altaee M. I. and Alinizy G.S., "Effect of Rhizobium leguminosarum biovar. Viciae bacteria on Broad Beans and Pea germination and growth and Its interactions with some pathogenic fungi", J. of research of basic education college, 8 (1), 2008.

[10] Chung S., Son C., Lee J. and Kim S., "Isolation and cultivation characteristics of Acetobacter xylinum $\mathrm{KJ}-1$ producing bacterial cellulose in shaking cultures", J. Microbiols and Biotech., 12, 722-728, 2002.

[11] Naja G.M., Mustin C. and Volesky B. A., "high resolution; a new approach to studying binding sites of microbial bio sorbent", Water Research., 39, 579-588, 2005.

[12] Ahmed M., Rafique Uddin M. and McLaughlin W., "Characterization of indigenous rhizobia from wild legume", FEMS Microbiol. Letters, 24, 197-203, 1984.

[13] Bernal G. and Graham P.H., "Diversity in the rhizobia associated with Phaseolus vulgaris L. in Ecuador, and comparisons with Mexican bean rhizobia", Canadian J. Microbiosl., 47, 519-526, 2001.

[14] Changjin S., Seonyong C., Jieun L. and Seongjun K., "Isolation and cultivation characteristics of Acetobacter Xylinum KJ1 producing bacterial cellulose in shaking culture", J. Microbiol. Biotechnosl., 12(5), 722-728, 2002.

[15] Masaoka S., Ohe T. and Sakota N., "Production of cellulose from glucose by Acetobacter xylinum", J. Ferment. Bioengs., 75, 18-22, 1993.

[16] Yamanaka S., Watanabe K., Kitamura N., Iguchi M., Mitsuhashi S., Nishi Y. and Uryr M., "The structure and mechanical properties of sheet prepared from bacterial cellulose", J. Mater. Sci., 24, 3141-3145, 1989.
[17] Raghunathan D., "Production of Microbial Cellulose from the New Bacterial Strains Isolated From Temple Wash Waters" Int. J. Curr. Microbiol. App. Sci., 2(12), 275-290, 2013.

[18] Esam J. and Inaam A., "Factors Influences on the yield of Bacterial Cellulose of Kombucha KhubdatHumza", Baghdad Science Journal, 11(3), 14201428, 2014.

[19] Pourramezan G.Z., Roayaei A.M. and Qezelbash Q.R., Optimizations of culture conditions for bacterial cellulose production by Acetobacter sp. 4B-2, Biotechnol., 8, 150-154, 2009.

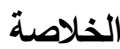

السيليلوز البكتيري هو نوع من البوليمرات الني نتتج من

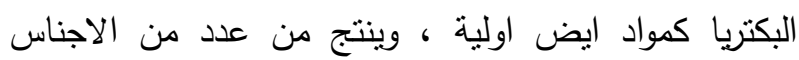
البكتيرية منل Acetobacter, Rhizobium , Sarcina Agrobacterium , Psuedomonas الى دراسة بعض العوامل المؤثرة في انتاج السليلوز من بكتريا Rhizobium leguminosarum bv. Viciae من العقد الجذرية لنبات الباقلاء المجموع من منطقة ابو غريب في بغداد، اختبر تاثير بعض العوامل البيئية والغذائية

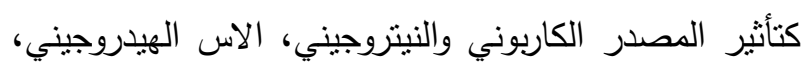

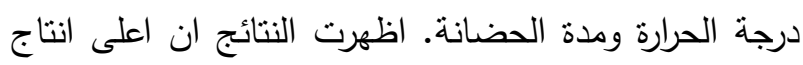
للسليلوز من بكتريا العقد الجذرية نم الحصول عليه عندما

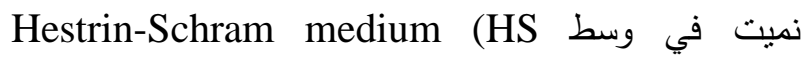
الحاوي على r medium)

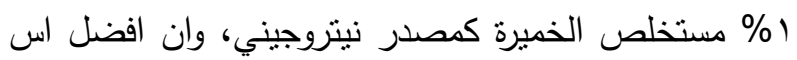

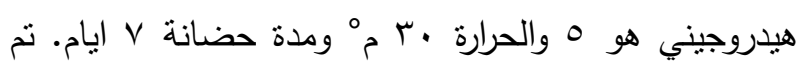

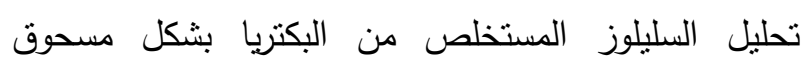
بواسطة تقنية قياس طيف الاشعة تحت الحمراء، واظهرت النتائج وجود المجاميع الوظيفية الفعالة للسليلوز البكتيري. 